\title{
Ligand Intermediates in Metal-Catalyzed Reactions
}

Final Technical Report. DE-FG03-93ER14321

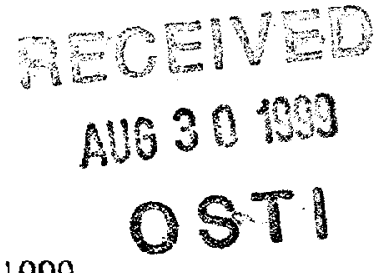

research perind summarized in report: 1-August-1996 through 31-July-1999

Exciting breakthroughs were made on a variety of projects, as summarized below.

A. Linkage Lsomerism in Imine Ligands that at Catalvtic Intermediates (paper 85).

Reaction of the amido complex $\left(\eta \eta^{5}-\mathrm{C}_{5} \mathrm{H}_{5}\right) \mathrm{Re}(\mathrm{NO})\left(\mathrm{PPh}_{3}\right)\left(\mathrm{NH}_{2}\right)(2)$ and hexafluoroacetone gives the methyleneamido complex $\left(\eta^{5}-\mathrm{C}_{5} \mathrm{H}_{5}\right) \mathrm{Re}(\mathrm{NO})(\mathrm{PPh})\left(\mathrm{N}=\mathrm{C}\left(\mathrm{CF}, \mathrm{H}_{2}\right)(3,58 \%)\right.$. Addition of TfOH to 3 yields the $\sigma$ imine complex $\left[\left(\eta^{5}-\mathrm{C}_{5} \mathrm{H}_{5}\right) \mathrm{Re}(\mathrm{NO})\left(\mathrm{PPh}_{3}\right)(\eta)\right.$. $\left.\left.\mathrm{N}(\mathrm{H})=\mathrm{C}\left(\mathrm{CF}_{3}\right)_{2}\right)\right]^{+} \mathrm{TfO}^{-}(4,96 \%)$. Similar reactions of 2 with trifluoroacetaldehyde and then TrOH give the $\sigma$ imine complex $\left[\left(\eta^{5}-\mathrm{C}_{5} \mathrm{H}_{5}\right) \operatorname{Re}(\mathrm{NO})\left(\mathrm{PPh}_{3}\right)\left(\eta^{1}-\mathrm{N}(\mathrm{H})=\mathrm{C}\left(\mathrm{CF}_{3}\right) \mathrm{H}\right)\right]^{-} \mathrm{TfO}^{-}(5$, $78 \%$ ), and sometimes small amounts of the corresponding $\pi$ trifluoroacetaldehyde complex. Reaction of 5 and $t$-BuO' $\mathrm{K}^{+}$gives the methyleneamido complex $\left(\eta^{5}-\mathrm{C}_{5} \mathrm{H}_{5}\right) \operatorname{Re}(\mathrm{NO})\left(\mathrm{PPh}_{3}\right)-$ $\left(\mathrm{N}-\mathrm{C}\left(\mathrm{CF}_{3}\right) \mathrm{H}\right)(6,82 \%)$. The IR and NMR properties of 3-6 are studied in detail. The ${ }^{13} \mathrm{C}$ NMR spectra show $C=N$ signals ( $157.142 \mathrm{ppm}$ ) diagnostic of $\sigma$ binding modes. No evidence is observed for $\pi$ isomers of 4 or 5. Analogous $\mathrm{O}=\mathrm{C}\left(\mathrm{CF}_{3}\right) \mathrm{X}$ complexes give exclusively $\pi$ isomers, and rationaies are discussed. Reactions of 3 or 6 with MeOTf and heteroatom electrophiles are also described.

\section{B. Phosphine Ligand Lability in Amido Complexes (paper 86).}

The diastereomerically and enantiomerically pure amido complex $(S R)-\left(\eta^{5}-C_{5} H_{5}\right) \mathrm{Re}-$ $(\mathrm{NO})\left(\mathrm{PPh}_{3}\right)\left(\mathrm{NHCH}\left(\mathrm{CH}_{3}\right) \mathrm{Ph}\right)((S R)-5)$ converts to $(R R)-5$ (inversion at rhenium. retention at carbon) in $\mathrm{THF}-d_{8}$ at $49.4^{\circ} \mathrm{C}$ with $\mathrm{k}_{-1}=2.34 \times 10^{-4} \mathrm{~s}^{-1}$ and $\mathrm{k}_{-1}=0.90 \times 10^{-4} \mathrm{~s}^{-1}$. Similarly, $(S S)-5$ converts to $(R S)-5$ with $\mathrm{k}_{1}=0.90 \times 10^{-4} \mathrm{~s}^{-1}$ and $\mathrm{k}_{-1}=2.30 \times 10^{-4} \mathrm{~s}^{-1}$. Both epimerizations give equilibrium ratios $(R R / S R$ or $S S / R S)$ of $70: 30$. Reactions with HOTf yield [ $\left(\eta^{5}\right.$ $\left.\left.\mathrm{C}_{5} \mathrm{H}_{5}\right) \mathrm{Re}(\mathrm{NO})\left(\mathrm{PPh}_{3}\right)\left(\mathrm{NH}_{2} \mathrm{CH}\left(\mathrm{CH}_{3}\right) \mathrm{Ph}\right)\right]^{+} \mathrm{TfO}$, and subsequent additions of $\mathrm{Et}_{4} \mathrm{~N}^{+} \mathrm{CN}^{-}$afford $\left(\eta^{5}-\mathrm{C}_{5} \mathrm{H}_{5}\right) \mathrm{Re}(\mathrm{NO})\left(\mathrm{PPh}_{3}\right)(\mathrm{CN})$ and $\mathrm{NH}_{2} \mathrm{CH}\left(\mathrm{CH}_{3}\right) \mathrm{Ph}$ (all steps with retention at rhenium and carbon). Enantiomeric purities and absolute configurations are assayed by chiral NMR shift reagents and $(-)$-menthyl chloroformate derivatives, respectively, establishing configurations of epimerized 5. Reaction of $(S R)-5$ and $P(p \text {-tol })_{3}$ in THF- $d_{8}$ at $49.4{ }^{\circ} \mathrm{C}$ gives $\left(\eta^{5}\right.$ $\left.\mathrm{C}_{5} \mathrm{H}_{5}\right) \mathrm{Re}(\mathrm{NO})\left(\mathrm{P}\left(\mathrm{p}-\mathrm{tol}_{3}\right)\left(\mathrm{NHCH}\left(\mathrm{CH}_{3}\right) \mathrm{Ph}\right)\left(50: 50\left(t_{0}\right) \rightarrow 66: 34\left(t_{\infty}\right) \mathrm{RR} / \mathrm{SR}\right)\right.$ with $\mathrm{k}=4.6 \times 10^{-}$ ${ }^{4} \mathrm{~s}^{-1}$, twice that for the conversion of $(S R)-5$ to $(R R)-5$. Rate data for the latter at $32.3-59.1^{\circ} \mathrm{C}$ give $\Delta H^{\ddagger}=26 \mathrm{kcal} / \mathrm{mol}$ and $\Delta \mathrm{S}^{\ddagger}=6 \mathrm{eu}$. These results are best modeled by mechanisms involving initial and rate determining $\mathrm{PPh}_{3}$ dissociation, with anchimeric assistance by the amido Ione pair, to give an intermediate that is trigonal planar at rhenium and combines with $\mathrm{PAr}_{3}$ without significant diastereoselectivity, Reactions of $n-B u L i$ with 5 and related complexes give $\mathrm{LiR}$ species from which $\mathrm{PPh}_{3}$ is lost at lower temperatures, and are presumed to be much less configurationally stable.

C. Synthesis Structure and Reactivity of Trimetallic Rhenium/Rhenium and Tetreametallic Rhenium/Osmium Carbide Complexes (paper 88).

Reaction of $\left(\eta^{5}-\mathrm{C}_{5} \mathrm{Me}_{5}\right) \operatorname{Re}(\mathrm{NO})\left(\mathrm{PPh}_{3}\right)(\mathrm{C} \equiv \mathrm{CLi})$ with $\operatorname{Re}_{2}(\mathrm{CO})_{10}$ and then $\mathrm{Me}_{3} \mathrm{O}^{+}$ $\mathrm{BF}_{4} \cdot$ gives the trirhenium $\mathrm{C}_{3} \mathrm{OMe}$ complex cis- $\left(\eta^{5}-\mathrm{C}_{5} \mathrm{Me}_{5}\right) \operatorname{Re}(\mathrm{NO})\left(\mathrm{PPh}_{3}\right)(\mathrm{C} \equiv \mathrm{CC}(\mathrm{OMe})=)$ $\operatorname{Re}(\mathrm{CO})_{4} \operatorname{Re}(\mathrm{CO})_{5}(3,92 \%)$. An analogous reaction with $\mathrm{O}_{3}(\mathrm{CO})_{12}$ gives heterotetrametallic $\left(\eta^{5}-\mathrm{C}_{5} \mathrm{Me}_{5}\right) \mathrm{Re}(\mathrm{NO})\left(\mathrm{PPh}_{3}\right)(\mathrm{C} \equiv \mathrm{CC}(\mathrm{OMe})=) \mathrm{Os}_{3}(\mathrm{CO})_{11}(4,87 \%)$. NMR. IR, and crystallographic data (4) show substantial contributions by ${ }^{+} \mathrm{Re}=\mathrm{C}=\mathrm{C}=\mathrm{C}(\mathrm{OMe})-\mathrm{M}^{-}$resonance forms. Reaction of 3 and excess $\mathrm{BF}_{3}$ gas in toluene precipitates $\left[\left(\eta^{5}-\mathrm{C}_{5} \mathrm{Me} e_{5}\right) \mathrm{Re}(\mathrm{NO})\left(\mathrm{PPh}_{3}\right)(\mu\right.$ $\left.\left.\eta^{1}: \eta^{3}: \eta^{1}-\mathrm{CCC}\right)\left(\operatorname{Re}(\mathrm{CO})_{4}\right) \operatorname{Re}(\mathrm{CO})_{5}\right]^{-} \mathrm{BF}_{4} \cdot(5,64 \%)$. A crystal structure shows a slightly bent $C_{3}$ moiety $\left(152(4)^{\circ}\right)$ that binds a rhenium on each end and spans a third. NMR, IR. and bond length data show that 5 is best viewed as a completely metalated $\pi$ propargyl or $\mathrm{PRe}=\mathrm{CC} \equiv \mathrm{C}-\mathrm{Re}(\mathrm{CO})_{5}$ adduct of $\operatorname{Re}(\mathrm{CO})_{4}$. It is likely derived by initial methoxide abstraction 


\section{DISCLAIMER}

This report was prepared as an account of work sponsored by an agency of the United States Government. Neither the United States Government nor any agency thereof, nor any of their employees, make any warranty, express or implied, or assumes any legal liability or responsibility for the accuracy, completeness, or usefulness of any information, apparatus, product, or process disclosed, or represents that its use would not infringe privately owned rights. Reference herein to any specific commercial product, process, or service by trade name, trademark, manufacturer, or otherwise does not necessarily constitute or imply its endorsement, recommendation, or favoring by the United States Government or any agency thereof. The views and opinions of authors expressed herein do not necessarily state or reflect those of the United States Government or any agency thereof. 


\section{DISCLAIMER}

Portions of this document may be illegible in electronic image products. Images are produced from the best available original document. 
from 3 to give a ReCCCReRe species, followed by rearrangement. Reaction of $\left(\eta^{5}-\mathrm{C}_{5} \mathrm{Me}_{5}\right)-$ $\operatorname{Re}(\mathrm{NO})\left(\mathrm{PPh}_{3}\right)\left(\mathrm{C} \equiv \mathrm{CC} \equiv \mathrm{CL}\right.$ i) with $\mathrm{Re}_{2}(\mathrm{CO})_{10}$ and then $\mathrm{Me}_{3} \mathrm{O}^{+} \mathrm{BF}_{4}^{-}$gives the $\mathrm{C}_{5} \mathrm{OMe}$ complex cis- $\left(\eta^{5}-\mathrm{C}_{5} \mathrm{Me} \mathrm{e}_{5}\right) \operatorname{Re}(\mathrm{NO})\left(\mathrm{PPh}_{3}\right)(\mathrm{C} \equiv \mathrm{CC} \equiv \mathrm{CC}(\mathrm{OMe})=) \operatorname{Re}(\mathrm{CO})_{4} \operatorname{Re}(\mathrm{CO})_{5}(8,44 \%)$. When 4 or $\mathbf{8}$ are treated with $\mathrm{BF}_{3}$ gas, $\mathrm{C}_{x}$ complexes are not detected.

D. Synthesis, Structure and Reactivity of Tetrametallic Rhenium/Osmium Carbide Complexes (papers 87 and 93).

Reaction of $\left(\eta^{5}-\mathrm{C}_{5} \mathrm{Me}_{5}\right) \operatorname{Re}(\mathrm{NO})\left(\mathrm{PPh}_{3}\right)(\mathrm{C} \equiv \mathrm{CH})$ and $\mathrm{Os}_{3}(\mathrm{CO})_{10}\left(\mathrm{NCCH}_{3}\right)_{2}\left(\mathrm{CH}_{2} \mathrm{Cl}_{2}\right.$. $\mathrm{RT})$ gives the $\mathrm{ReC} \mathrm{O}_{3}$ complex $\left(\eta^{5}-\mathrm{C}_{5} \mathrm{Me}_{5}\right) \mathrm{Re}(\mathrm{NO})\left(\mathrm{PPh}_{3}\right)(\mathrm{CC}) \mathrm{Os}_{3}(\mathrm{CO})_{10}(\mathrm{H})(2,78 \%)$. A crystal structure shows that the hydride and ReCC terminus symmetrically bridge the same two osmium atoms. The ReC and ReCC bond lengths, and IR and NMR properties, indicate contributions by both $\mathrm{Re}-\mathrm{C} \equiv \mathrm{C}-\left(\mathrm{Os}_{3}\right)$ and $+\mathrm{Re}=\mathrm{C}=\mathrm{C}=\left(\mathrm{O}_{3}\right)^{-}$resonance forms. Analogous $\mathrm{Re}-$ $\mathrm{C}_{4} \mathrm{Os}_{3}(4,83 \%)$ and $\mathrm{ReC}_{6} \mathrm{Os}_{3}(6,61 \%)$ complexes are similarly prepared, and are progressively less stable in solution and the solid state. Cyclic voltammograms of 2, 4, and 6 show partially reversible oxidations. Complex 4 decarbonylates in refluxing hexane to give $\left.\left(\eta^{5}-\mathrm{C}_{5} \mathrm{Me}\right)_{5}\right)-$ $\operatorname{Re}(\mathrm{NO})\left(\mathrm{PPh}_{3}\right)(\mathrm{CCCC}) \mathrm{Os}_{3}(\mathrm{CO})_{9}(\mathrm{H})(57 \%)$, in which the $\mathrm{ReCCCC}$ terminus bonds to three osmium atoms and the adjacent carbon (and hydride) to two. Reaction of 2 and $\mathrm{HBF}_{4} \cdot \mathrm{E}_{2} \mathrm{O}$ gives $\left[\left(n^{5}-\mathrm{C}_{5} \mathrm{Me}_{5}\right) \mathrm{Re}(\mathrm{NO})\left(\mathrm{PPh}_{3}\right)(\mathrm{CC}) \mathrm{Os}_{3}(\mathrm{CO})_{10}(\mathrm{H})_{2}\right]^{-} \mathrm{BF}_{4}-(69 \%)$. A crystal structure of the $\mathrm{SbF}_{6}$ salt shows a $\mathrm{ReC}_{2} \mathrm{Os}_{3}$ unit very similar to that of 2 , with the hydrides bridging different osmium-osmium bonds. The $\mathrm{C}_{3} \mathrm{OMe}$ complex $\left(\eta^{5}-\mathrm{C}_{5} \mathrm{Me}_{5}\right) \mathrm{Re}(\mathrm{NO})\left(\mathrm{PPh}_{3}\right)(\mathrm{C} \equiv \mathrm{CC}(\mathrm{O}-$ $\mathrm{Me})=\mathrm{Os}_{3}(\mathrm{CO})_{11}$ decarbonylates in refluxing heptane to give $\left(\eta^{5}\left(\mathrm{C}_{5} \mathrm{Me}\right) \mathrm{Re}(\mathrm{NO})\left(\mathrm{PPh}_{3}\right)-\right.$ $(\mathrm{CCC}) \mathrm{Os}_{3}(\mathrm{CO})_{9}(\mathrm{OMc})(63 \%)$, in which the ReCCC terminus bonds to three osmium atoms. and the center carbon bonds to the osmium that is not methoxide-bridged. A crystal structure shows the ReCCC carbon to be highly distorted. bonding to four atoms that fall on one side of a plane through the carbon.

E. Synthesis, Structure and Reactivity of Heterobimetallic Complexes with $C_{3}$ and $C_{5}$ Carbide Bridges (paper 94).

Reactions of $\left(\eta^{5}-\mathrm{C}_{5} \mathrm{Me}_{5}\right) \operatorname{Re}(\mathrm{NO})\left(\mathrm{PPh}_{3}\right)(\mathrm{C} \equiv \mathrm{CLi})$ with $\mathrm{W}(\mathrm{CO})_{6}, \mathrm{Fe}(\mathrm{CO})_{5}$ or $\mathrm{Mn}$ $(\mathrm{CO})_{3}\left(\eta^{5}-\mathrm{C}_{5} \mathrm{H}_{n} \mathrm{Cl}_{5-n}\right)$, followed by $\mathrm{Me}_{3} \mathrm{O}^{-} \mathrm{BF}_{4}^{-}$, give the heterobimetall ic $\mathrm{C}_{3} \mathrm{OMe}$ complexes $\left(\eta^{5}-\mathrm{C}_{5} \mathrm{Me}_{5}\right) \operatorname{Re}(\mathrm{NO})\left(\mathrm{PPh}_{3}\right)(\mathrm{C} \equiv \mathrm{CC}(\mathrm{OMe})=) \mathrm{M}(\mathrm{CO})_{x}\left(\eta^{5}-\mathrm{C}_{5} \mathrm{H}_{n} \mathrm{Cl}_{5-n}\right)_{1}(\mathrm{M} / x / y / n=3$, W/5/0/-; 4, $\mathrm{Fe} / 4 / 0 /-; 5, \mathrm{Mn} / 2 / 1 / 5 ; 6, \mathrm{Mn} / 2 / 1 / 4: 7, \mathrm{Mn} / 2 / 1 / 0)$. Spectroscopic and crystallographic (3) data indicate contributions by ${ }^{+} \mathrm{Re}=\mathrm{C}=\mathrm{C}=\mathrm{C}(\mathrm{OMe})-\mathrm{M}^{-}$resonance forms. Reactions of $4-7$ and $\mathrm{BF}_{3}$ gas give the title compounds $\left[\left(\eta^{5}-\mathrm{C}_{5} \mathrm{Me} \mathrm{e}_{5}\right) \operatorname{Re}(\mathrm{NO})\left(\mathrm{PPh}_{3}\right)(\mathrm{CCC}) \mathrm{M}(\mathrm{CO})_{x}\left(\eta^{5}-\mathrm{C}_{5} \mathrm{H}_{n} \mathrm{Cl}_{5-n}\right)_{y}\right.$ $(\mathrm{M} / x / y / n=9, \mathrm{Mn} / 2 / 1 / 5 ; 10, \mathrm{Mn} / 2 / 1 / 4 ; 11, \mathrm{Mn} / 2 / 1 / 0 ; 12$. Fe/4/0/.). Spectroscopic and crystallographic (9) data indicate dominant contributions by fully cumulated $\mathrm{Re}=\mathrm{C}=\mathrm{C}=\mathrm{C}=\mathrm{Mn}$ resonance forms. Reactions of $\left(\eta^{5}-\mathrm{C}_{5} \mathrm{Me}\right) \mathrm{Re}(\mathrm{NO})\left(\mathrm{PPh}_{3}\right)(\mathrm{C} \equiv \mathrm{CC} \equiv \mathrm{CLi})$ with $\mathrm{Mn}(\mathrm{CO})_{3}\left(\eta^{5}-\right.$ $\left.\mathrm{C}_{5} \mathrm{Cl}_{5}\right), \mathrm{Mn}(\mathrm{CO})_{3}\left(\eta^{5}-\mathrm{C}_{5} \mathrm{Br}_{5}\right)$, or $\mathrm{Fe}(\mathrm{CO})_{5}$, followed by $\mathrm{Me}_{3} \mathrm{O}^{-} \mathrm{BF}_{4}{ }^{-}$, give the $\mathrm{C}_{5} \mathrm{OMe}$ complexes $\left(\eta^{5}-\mathrm{C}_{5} \mathrm{Me}_{5}\right) \operatorname{Re}(\mathrm{NO})\left(\mathrm{PPh}_{3}\right)(\mathrm{C} \equiv \mathrm{CC} \equiv \mathrm{CC}(\mathrm{OMe})=) \mathrm{M}(\mathrm{CO})_{2}\left(\eta^{3}-\mathrm{C}_{5} \mathrm{X}_{5}\right),(\mathrm{M} / x / y / \mathrm{X}=16$, $\mathrm{Mn} / 2 / 1 / \mathrm{Cl} ; 19, \mathrm{Mn} / 2 / 1 / \mathrm{Br} ; 20, \mathrm{Fe} / 4 / 0 /-)$. However, $\mathrm{Mn}(\mathrm{CO})_{3}\left(\mathrm{n}^{5}-\mathrm{C}_{5} \mathrm{H}_{5}\right)$ does not react. Reaction of 16 and $\mathrm{BF}_{3}$ gives the $\mathrm{C}_{5}$ complex $\left[\left(\eta^{5}-\mathrm{C}_{5} \mathrm{Me}_{5}\right) \operatorname{Re}(\mathrm{NO})\left(\mathrm{PPh}_{3}\right)(\mathrm{CCCCC}) \mathrm{Mn}(\mathrm{CO})_{2}\left(\eta^{5}-\right.\right.$ $\left.\left.\mathrm{C}_{5} \mathrm{Cl}_{5}\right)\right]^{+} \mathrm{BF}_{4}^{-}(21)$ as a light-sensitive deep brown powder of $>94 \%$ purity. IR and NMR data show a dominant ${ }^{+} \mathrm{Re}=\mathrm{C}=\mathrm{C}=\mathrm{C}=\mathrm{C}=\mathrm{C}=\mathrm{Mn}$ resonance form. UV-visible spectra of 9-11 and 21 show intense absorptions at $392,396,414$, and $480 \mathrm{~nm}(\varepsilon 55800,50900,49100$, $60500 \mathrm{M}^{-1} \mathrm{~cm}^{-1}$ ), respectively, and weaker longer wavelength bands. These are believed to have appreciable rhenium-to-manganese charge transfer character.

\section{E Synthesis. Structure, and Reactivity of Dirhenium Complexes with CN bridges (paper 90).}

Reactions of $\left(\eta^{5}-C_{5} R_{5}\right) \operatorname{Re}(N O)\left(P P h_{3}\right)(O T f)\left(1 a / b, R^{\prime}=H / M e\right)$ and $\left(\eta^{5}-C_{5} R_{5}\right) \operatorname{Re}(N O)$ $\left(\mathrm{PPh}_{3}\right)(\mathrm{CN})(2 \mathrm{a} / \mathrm{b}, \mathrm{R}=\mathrm{H} / \mathrm{Me})$ in toluene or $\mathrm{CH}_{2} \mathrm{Cl}_{2}$ give the title complexes $\left(\mathrm{R} / \mathrm{R}^{\prime}=\mathrm{H} / \mathrm{H}(4 \mathrm{a})\right.$, $\mathrm{Me} / \mathrm{H}(4 \mathrm{~b}), \mathrm{H} / \mathrm{Me}(4 \mathrm{c}), \mathrm{Me} / \mathrm{Me}(4 \mathrm{~d}))$ in $71-91 \%$ yields as $>99:<1,99-88: 1-12,95-66: 5-34$, and 71-60:29-40 mixtures of $S R . R S / S S, R R$ diastereomers (pseudo meso/dl). Reaction of (S)-1a and $(R)-2$ a gives $(R R)-4 a$ (retention) - a diastereomer not formed from the racemates. IR and NMR spectra of $4 a-d$ are analyzed, especially with reference to the cyanide ligands and charge distribution. Cyclic voltammetry shows pseudoreversible oxidations that become thermodynamicaily more favorable with increased numbers of pentamethylcyclopentadienyl ligands. A 
crystal structure of (SR,RS)-4a shows a slightly bent ReCNRe linkage, bond lengths close to those of related $\mathrm{ReC} \equiv$ and $\mathrm{RC} \equiv \mathrm{NRe}$ compounds, and van der Waals contacts across the bridge. The diastereomers of $\mathbf{4 a - d}$, and linkage isomers $\mathbf{4 b}$.c , do not equilibrate in $\mathrm{CDCl}_{3}(55$ $\left.{ }^{\circ} \mathrm{C}\right)$ or $\mathrm{CHCl}_{2} \mathrm{CHCl}_{2}\left(98^{\circ} \mathrm{C}\right)$. The dissociation of $4 \mathbf{a}, \mathbf{d}$ to $1 \mathbf{a} / \mathbf{2} \mathbf{a}$ or $\mathbf{1} \mathbf{b} / \mathbf{2} \mathbf{b}$ is excluded by unsuccessful trapping experiments involving $\mathbf{1 a}, \mathbf{b}, \mathbf{2} \mathbf{a}, \mathbf{b}$ and diallyl sulfide $\left(25-120^{\circ} \mathrm{C}\right)$. Howev$\mathrm{er}$, the diallyl sulfide complex $\left[\left(\mathrm{n}^{5}-\mathrm{C}_{5} \mathrm{H}_{5}\right) \mathrm{Re}(\mathrm{NO})\left(\mathrm{PPh}_{3}\right)\left(\mathrm{S}\left(\mathrm{CH}_{2} \mathrm{CH}^{2} \mathrm{CH}_{2}\right)_{2}\right)\right]^{+} \mathrm{TfO}^{-}$and 2a react $\left(\mathrm{CHCl}_{2} \mathrm{CHCl}_{2}, 96^{\circ} \mathrm{C}\right)$ to give $4 a(75-63 \%: 50: 50 \mathrm{SR}, \mathrm{RS} / S S, R R)$. These data show the cyanide bridges to have exceptional kinetic and thermodynamic stabilities.

G. Cumplexes and Catalysts Immobilized in Fluorinated Solvents: Mechanistic Studies (papers 89 and 92).

The reaction of $[\operatorname{Ir}(\mathrm{Cl})(\mathrm{cod})]_{2}, \mathrm{P}\left(\mathrm{CH}_{2} \mathrm{CH}_{2}\left(\mathrm{CF}_{2}\right)_{5} \mathrm{CF}_{3}\right)_{3}$, and $\mathrm{CO}(\mathrm{l}$ atm $)$ gives the title compound $(2,97 \%)$. Tri(n-octyl) phosphine (3) and rhodium (4) analogs are similarly prepared. Crystal structures of 2 and 4 show anti CCCC conformations in the six perfluoroalkyl grcups (average torsion angle $169^{\circ}$ ), with four chains (two per phosphorus) in parallel coplanar arrays that define ca. $21 \times 6 \AA$ "rafts". The other two chains extend on a common side of the raft, which pack back-to-back in stacks, maximizing parallel chains in every dimension. DSC shows one phase transition (melting, $2 / 475 / 79^{\circ} \mathrm{C}$ ) prior to thermal decomposition $\left(>200^{\circ} \mathrm{C}\right.$ ). The IR ${ }^{y} \mathrm{CO}$ values $\left(2 / 3 / 41975 / 1942 / 1979 \mathrm{~cm}^{-1}\right)$ show that the $\mathrm{CH}_{2} \mathrm{CH}_{2}$ spacers do not completely insulate the metals from the perfluoroalkyl groups. Both 2 and 4 are soluble in $\mathrm{CF}_{3} \mathrm{C}_{6} \mathrm{~F}_{11} \mathrm{CF}_{3} \mathrm{C}_{6} \mathrm{H}_{5}$, ether, THF and acetone, but insoluble in hexane, toluene, $\mathrm{ClICl}_{3}$, and $\mathrm{CH}_{2} \mathrm{Cl}_{2}\left(\mathrm{CF}_{3} \mathrm{C}_{6} \mathrm{~F}_{1} / \mathrm{THF}\right.$ partition coefficient $\left.>99.7:<0.3\right)$. Reactions of 2 with $\mathrm{RI}, \mathrm{H}_{2}$, and ${ }^{3} \mathrm{O}_{2}$ or ${ }^{9} \mathrm{O}_{2}$ in $\mathrm{CF}_{3} \mathrm{C}_{6} \mathrm{~F}_{11}$ give $\mathrm{Ir}(\mathrm{CO})(\mathrm{Cl})(\mathrm{R})(\mathrm{I})\left[\mathrm{P}\left(\mathrm{CH}_{2} \mathrm{CH}_{2}\left(\mathrm{CF}_{2}\right)_{5} \mathrm{CF}_{3}\right)_{3}\right]_{2}\left(\mathrm{R}=\mathrm{CH}_{2} \mathrm{CH}_{2^{-}}\right.$ $\left.\left(\mathrm{CF}_{2}\right)_{7} \mathrm{CF}_{3} / \mathrm{CH}_{3} / \mathrm{CH}\left(\mathrm{CH}_{3}\right) \mathrm{CH}_{2} \mathrm{CH}_{3}, 5 / 6 / 7,70-84 \%\right), \operatorname{Ir}(\mathrm{CO})(\mathrm{Cl})(\mathrm{H})_{2}\left[\mathrm{P}\left(\mathrm{CH}_{2} \mathrm{CH}_{2}\left(\mathrm{CF}_{2}\right)_{5}-\right.\right.$ $\left.\left.\mathrm{CF}_{3}\right)_{3}\right]_{2}(82 \%)$, and $\operatorname{Ir}(\mathrm{CO})(\mathrm{Cl})\left(\mathrm{O}_{2}\right]\left[\mathrm{P}\left(\mathrm{CH}_{2} \mathrm{CH}_{2}\left(\mathrm{CF}_{2}\right)_{5} \mathrm{CF}_{3}\right)_{3}\right]_{2}(9.67 \%)$, respectively. Additions of RI occur by free-radical chain mechanisms (inhibition by duroquinone; slower dark reactions: rates $7>5>6$ ), with no evidence for polar pathways. Complex 9 forms more rapidly in THF, indicating that (relative to THF) 2 and ${ }^{3} \mathrm{O}_{2}$ are stabilized by $\mathrm{CF}_{3} \mathrm{C}_{6} \mathrm{~F}_{11}$ more than the transition state.

H. Complexes and Catalysts Immobilized in Fluorinated Solvents: Practical Methods for Catalysis (paper 95).

Fluorous solvents commonly exhibit temperature-dependent miscibilities with organic solvents. Thus, catalysts and reagents that have high affinities for fluorous solvents can be used in protocols that combine the advantages of one-phase chemistry (higher temperature) and biphase product separation (lower temperature). This review provides a "how to" guide with respect to solvent sources, and solubility and polarity characteristics. All currently available partition coefficients for fluorous catalysts and reagents, as well as various educts and products, are tabulated.

\section{Exploratory Polyoxotungstate Chemistry (paper 91 ).}

Reaction of the chiral racemic carbonyl complex $\left[\left(\eta^{5} \cdot \mathrm{C}_{5} \mathrm{H}_{5}\right) \mathrm{Re}(\mathrm{NO})\left(\mathrm{PPh}_{3}\right)(\mathrm{CO})\right]^{+}$ $\mathrm{BF}_{4}{ }^{-}$and $\left\{\left(n-\mathrm{C}_{4} \mathrm{H}_{9}\right)_{4} \mathrm{~N}^{+}\right\}_{2}\left[\mathrm{~W}_{6} \mathrm{O}_{19}\right]^{2-}$ in DMF, followed by addition of $\mathrm{CH}_{2} \mathrm{Cl}_{2}$ and hexane, gives the title compound as yellow prisms $(78 \%)$. A crystal structure (triclinic, $\mathrm{P}, a / b / c=$ $\left.9.545(2) / 9.687(2) / 16.226(4) A, \alpha / B / \gamma=102.46(2) / 105.88(2) / 87.79(2)^{\circ}, Z=1\right)$ shows opposite enantiomers of the cations arrayed about a dianion-based inversion center - a meso assembly. The enantiomerically pure carbonyl complex gives crystals with the same unit cell, but P1 space group. This is possible due to the comparable sizes of the nitrosyl and carbonyl ligands. Metrical parameters are close to those of related compounds in the literature. 


\section{PUBLICATIONS FROM CLRRENT PROJECT PERIOD}

85. "A Search for $\pi / \sigma$ Equilibria in Chiral Rhenium Imine Complexes of the Formula $\left[\left(\eta^{5}\right.\right.$. $\left.\left.\mathrm{C}_{5} \mathrm{H}_{5}\right) \operatorname{Re}(\mathrm{NO})\left(\mathrm{PPh}_{3}\right)\left(\mathrm{N}(\mathrm{H})=\mathrm{C}\left(\mathrm{CF}_{3}\right) X\right)\right]^{+} \mathrm{TfO}^{-} ;$An Investigation of Electronic Effects Upon the Binding Mode", Stark, G. A.; Gladysz, J. A. Inorg. Chem. 1996, 35, 55095513.

86. "Configurational Equilibria in Amido and Lithioamido Complexes of Formulas $\left(\eta^{5}-\mathrm{C}_{5}\right.$ $\left.\mathrm{H}_{5}\right) \mathrm{Re}(\mathrm{NO})\left(\mathrm{PAr}_{3}\right)\left(\mathrm{N}, \mathrm{HCHRR}^{\prime}\right)$ and $\left(\eta^{5}-\mathrm{C}_{5} \mathrm{H}_{5}\right) \mathrm{Re}(\mathrm{NO})\left(\mathrm{PAr}_{3}\right)\left(\mathrm{N}, \mathrm{LiR}^{\prime \prime}\right)$ : Epimerization Occurs at Rhenium via Phosphine Dissociation", Dewey, M. A.; Stark, G. A.; Gladysz, J. A. Organometallics 1996, 15, 4798-4807.

87. "Methods for Attaching Metal-Capped sp Carbon Chains to Metal Clusters: Synthesis, Structure, and Reactivity of Rhenium/Triosmium Carbon Complexes of the Formula $\left(\eta^{5}-\mathrm{C}_{5} \mathrm{Me}_{5}\right) \operatorname{Re}(\mathrm{NO})\left(\mathrm{PPh}_{3}\right)(\mathrm{CC})_{n} \mathrm{Os}_{3}(\mathrm{CO})_{10}(\mathrm{H})^{\prime \prime}$, Falloon, S. B.; Arif, A. M.; Gladysz, J. A. J. Chem. Soc. Chem. Commun. 1997, 629-630.

88. "Synthesis, Structure, and Reactivity of Polymetallic $\mathrm{C}_{3} \mathrm{OMe}$ Complexes of the Formula $\left(\eta^{5}-\mathrm{C}_{5} \mathrm{Me}_{5}\right) \operatorname{Re}(\mathrm{NO})\left(\mathrm{PPh}_{3}\right)\left(\mathrm{C} \equiv \mathrm{CC}(\mathrm{OMe})=\mathrm{M}_{\mathrm{m}}(\mathrm{CO})_{\mathrm{n}}(\mathrm{M} / \mathrm{m} / \mathrm{n}=\mathrm{Re} / 2 / 9, \mathrm{Os} / 3 / 11): \mathrm{A}\right.$ New Form of Coordinated Carbon in which a $C_{3}$ Chain Links two Metals and Spans a Third", Falloon, S. B.; Weng, W.; Arif, A. M.; Gladysz, J. A. Organometallics 1997, $16,2008-2015$.

89. "Synthesis, Structure, and Oxidative Additions of a Fluorous Analog of Vaska's Complex, trans- $\operatorname{Ir}(\mathrm{CO})(\mathrm{Cl})\left[\mathrm{P}\left(\mathrm{CH}_{2} \mathrm{CH}_{2}\left(\mathrm{CF}_{2}\right)_{5} \mathrm{CF}_{3}\right)_{3}\right]_{2}$; Altered Reactivity in Fluorocarbons, and Implications for Catalysis", Guillevic, M.-A.; Arif, A. M.; Horváth. I. T.; Gladysz, J. A. Angew. Chem. Int. Ed. Engl. 1997, 36, 1612-1615.

90. "Synthesis, Structure, and Reactivity of Bridging Cyanide Complexes of the Formula $\left[\left(\eta^{5}-\mathrm{C}_{5} \mathrm{R}_{5}\right) \operatorname{Re}(\mathrm{NO})\left(\mathrm{PPh}_{3}\right) \mathrm{CN}\left(\mathrm{Ph} \mathrm{H}_{3} \mathrm{P}\right)(\mathrm{ON}) \operatorname{Re}\left(\eta^{5}-\mathrm{C}_{5} \mathrm{R}_{5}\right)\right]^{-} \mathrm{TfO}-\left(\mathrm{R}, \mathrm{R}^{\prime}=\mathrm{H}, \mathrm{Me}\right) "$, Stark, G. A.; Arif, A. M.; Gladysz, J. A. Organometallics 1997, 16, 2909-2918.

91. "Synthesis and Crystallographic Characterization of the 'Sometimes-Chiral' Dirhenium Polyoxoungstate Salt $\left.\left\{\left(\eta^{5}-\mathrm{C}_{5} \mathrm{H}_{5}\right) \operatorname{Re}(\mathrm{NO})\left(\mathrm{PPh}_{3}\right)(\mathrm{CO})\right]^{-}\right\}_{2}\left[\mathrm{~W}_{6} \mathrm{O}_{19}\right]^{2-1}$, Amoroso, A. J.; Arif, A. M.; Gladysz, J. A. Bull. Soc. Chim. Fr. 1997, 134, 793-799.

92. "Organometallic Reactivity Patterns in Fluorocarbons, and Implications for Catalysis; Synthesis, Structure, Solubility, and Oxidative Additions of a Fluorous Analog of Vaska's Complex, trans- $\operatorname{Ir}(\mathrm{CO})(\mathrm{Cl})\left[\mathrm{P}\left(\mathrm{CH}_{2} \mathrm{CH}_{2}\left(\mathrm{CF}_{2}\right)_{5} \mathrm{CF}_{3}\right)_{3}\right]_{2}{ }^{\prime \prime}$, Guillevic, M.-A.; Rocaboy, C.; Arif, A. M.; Horváth, I. T.; Gladysz, J. A. Organometallics 1998, 17, 707-717.

93. "Attaching Metal-Capped sp Carbon Chains to Metal Clusters: Synthesis, Structure, and Reactivity of Rhenium/Triosmium Complexes of Formula $\left[\left(\eta^{5}-\mathrm{C}_{5} \mathrm{Me} \mathrm{H}_{5}\right) \operatorname{Re}(\mathrm{NO})\right.$ $\left.\left(\mathrm{PPh}_{3}\right)(\mathrm{CC})_{n} \mathrm{Os}_{3}(\mathrm{CO})_{v}(\mathrm{X})_{2}\right]^{\mathrm{m}+}$, Including Carbon Geometries more Distorted than Planar Tetracoordinate", Falloon, S. B.; Szafert, S.; Arif, A. M.; Gladysz, J. A. Chem. Eur. J. 1998 4, 1033-1042.

94. "New Forms of Coordinated Carbon: Wire-Like Cumulenic $C_{3}$ and $C_{5}$ sp Carbon Chains that Span Two Different Transition Metals and Mediate Charge Transfer", Bartik, T.; Weng, W.; Ramsden, J. A.; Szafert, S.; Falloon S. B.; Arif, A. M.; Gladysz, J. A. J. Am. Chem. Soc. 1998, 120, 11071-11081.

95. "Chemistry in Fluorous Media: A User's Guide to Practical Considerations in the Application of Fluorous Catalysts and Reagents", Barthel-Rosa, L.; Gladysz, J. A. Coord. Chem. Rev. 1999. in press 